\title{
Exploring the Reading Strategies Used by Male and Female Students
}

\author{
Yulia Efnawati ${ }^{1, *}$ Mukhaiyar $^{1}$ \\ ${ }^{I}$ English Education Graduate Program, Universitas Negeri Padang, Padang, Indonesia \\ *Corresponding author.Email: yuliaefnawati66@gmail.com
}

\begin{abstract}
Reading strategy had been considered as the obligatory to the EFL learners. Reading strategy is a learning technique to enable the students to comprehend the text well and make them become a high proficiency level of readers. This study aims to find out what reading strategy used by male and female EFL learners. This study used document analysis as a research design to collect the data. It also used to strengthen the procedure to find out the usage of reading strategy. The results showed the significant differences of the strategy used between male and female students. Male students are greater strategy use than Female on memory, cognitive, and compensatory strategy, while the female students are reported as high strategy used on social-effective strategy and metacognitive strategy. The findings suggest the teacher to consider the way of teaching reading in the class due to the finding research which is the use of reading strategy by male and female students, and for the students, they can build the process of their comprehension using the strategy which are appropriate to their reading needs.
\end{abstract}

Keywords: reading, reading strategy, male and female

\section{INTRODUCTION}

Reading is the activity to search information from a certain source. It is important if we keep doing reading activity [1], it can develop our mind, improve our memory and it can also develop our knowledge and creativity. In learning English, reading is needed to add the language sources of the students. English lessons specifically in the field of reading are needed to be taught and become the most important thing to learn [2]. Moreover, reading is a thinking process. The process of reading is an activity to collect and build the meaning from words or cluster of words. Reading is a set of skills include making sense of deriving meaning from printed word [3], [4]. It means that reading activity is not only the process of record the printed word, but also when someone read the text, he gets the message from the text.

Reading skills emphasize students to learn how to discover and master the contents of reading. However, it is difficult especially to the learners of English as foreign language to build their thinking process. It makes reading skill become the most important to be mastered by the EFL students. Having a good ability in reading comprehension helps the students through the reading test. In reading comprehension, students are required to know the reading content related to the main idea by involving visual information and non-visual information. In order to achieve the goals of reading comprehension, the learners need to provide reading strategy and taught about it in order to build their process of learning [5].

Reading strategy is a learning technique to enable the students to comprehend the text well and make them become a high proficiency level of readers. EFL learners are required to know the importance of reading strategy. It is necessary because it can help students' learning process in comprehend the text and achieve their goals in reading [6], by then it supposed to give the positive impact and affect the reading ability in English as foreign language [7]. The importance of reading strategy considers the learners if they found something missing in the text, they know how to react and enable them to catch up about what they read [8]. The consider of using a variety of reading strategies can help them more capable in language acquisition and find concrete detailed information of the text. However, many students do not realize the importance of reading strategy. The lack of students' awareness in applying the reading strategy is one of the causes of many difficulties they face in reading comprehension. For this reason, it is important for the students to apply a reading strategy that is appropriate for their reading needs.

Reading strategies are divided into several categories namely the Strategy Inventory for Language Learning (SILL) [9], which are: cognitive strategy, meta-cognitive strategy, memory strategy, compensatory strategy, affective strategy, and social strategy. Cognitive strategy is a kind of strategy when the students use their mind receiving and sending a message through some sources in the text, searching the detailed information of the text fast by skimming and scanning and analyzing some expressions. Meta-cognitive is a category of strategy that enable students to do the actions beyond the cognitive strategy, such as making plan before they start reading and 
helping them to arrange their language to be efficient and effective way. Then, memory is a way of students to catch up the meaning of the contents by drawing a picture of words or phrases and making association of their prior knowledge with the information they get from the text. Compensatory strategy is a kind of step to use a new language to further comprehension despite they have limitation of knowledge. Affective strategy is related to the student's emotion, they try to calm down their anxiety and encourage themselves. Finally, social strategy is a strategy used when the students asking questions to others, cooperating with friends, and emphasizing with others.

Some classifications of reading strategy are modified such as metacognitive strategy renamed as global strategy, and cognitive strategy become problem-solving strategy [10]. Besides that, there is additional strategy which is support strategy [11]. It is when the students use some kinds of tools to help them understand the text like dictionary to search a difficult word, taking notes, summarizing, and highlighting the important words or sentences.

The relation between male and female and reading strategy still being a gap in reading research. Students' skill and reading achievement is also affected by gender [1]. It is caused by the biological differences which make male and female differ on social and cultural. Male and female found themselves difference in reaching their education goals. In reading skill, female students are a great reader than male [12]. They significantly outperform in general study strategies, searching and sending a meaning and also get themselves management strategies. The aspects related to males and females encourage the researcher to investigate the issue of student's learning styles, especially in reading comprehension.

\section{METHODOLOGY}

A descriptive method is used as a research design. Document analysis design was used in this research to strengthen the procedure to find out the usage of reading strategy. In relation to that, the data of this research were collected from the accredited journals. In this case, the documents are journal of reading strategy. There are 7 accredited journals that become the sources of data for this research, namely:

1. Gender Differences in Reading Strategy Use among ESL College Students [11].

2. The Reading Strategies Used by Male and Female Colombian University Students [13].

3. A Study of the Selection of Reading Strategies among Genders by EFL College Students [14].

4. Online Reading Strategy Use and Gender Differences: The Case of Iranian EFL Learners [15].

5. Diversity in Utilization of Reading Strategies: A Cross Gender Study on Iranian EFL Learners [7]

6. The Use of EFL Reading Strategies among High School Students in Taiwan [16].

7. The Usage of Reading Strategies between Male and Female Malaysia Undergraduate Students: A Preliminary Study [5].
Moreover, after collecting the data from the documents, the data analysed qualitatively. Before that, the data were compared and identified to separate the suitable data that can be presented in this research. The data was done by classifying the findings of all the journals.

\section{RESULTS AND DISCUSSION}

The results of data by looking after some accredited journals as the sources of the data, it is found that on the first article showed that between male and female are the same in their overall reading strategy use [1]. They only differ on two individual strategy which are one in global strategy which is making note of the text characteristic and one in support strategy which is paying close attention to the text. In this study, Male and female are both in high frequency strategy use. Both male and female use the same strategy in a high frequency that is problem-solving strategy and support strategies were used in medium frequency. In this study, there is no low frequency of reading strategy use between males and females. So, the conclusion was there was no differences between male and female in this study.

Second article investigated about reading strategy used by Colombian male and female in Bogota [13]. The results indicate that male and female use different strategy. The most commonly used of reading strategy by males was they try to get back on track when they lose their concentration during reading the text. It is a sub-category of problem-solving strategy. Males are seldom in using support strategy which is read aloud the text to help them get more understanding about what they read. Then, the results for females in the most commonly use of strategy was in the sub-category of problem-solving strategy, that is the same with males when they go back on track or they repeat their reading to get back their concentration while they are reading. Then, the least common strategy used by females was asking themselves a question to answered in the text which is sub-category in support strategy. So, it can conclude that in the overall strategy females are high frequency used than males.

The third article aims to search the reading strategy used by male and female college students [14]. The results of this study indicated that there are significant differences between male and female in the reading strategy used. Males are the greater strategy used than females on memory strategy, cognitive strategy, and compensation strategy. While females are greater strategy used than males on metacognitive strategy and social effective strategy. The most commonly used of strategy by male students was reading English article, they like to study or read English articles and the least commonly strategy used was guessing, they guessing the words from the context of the text. The most commonly used of strategy by female students was setting a plan, they always make plan or arrange the purpose before reading the text and the least frequently used of strategy by female students was guessing unfamiliar words from the text from. 
Then, the article investigated the online strategies used by Iranian male and females EFL students [15]. The results showed that they found no differences between male and female in the reading strategy used. Both male and female use the same strategy with the high frequency which are problem-solving strategy and global reading strategy. They only differ on the individual reading strategy. In this research found that male tend to do the actions or strategy such as doing live chatting with other learners if they don't understand about the text, it is the sub-category from global strategy. Then, they like to do adjusting reading speed to control they comprehension during reading and or pausing and thinking about what they read, it is subcategory from problem-solving strategy. Last, male students in this study like to do paraphrasing the sentences for better understanding, the paraphrasing is aimed to get better summarizing. The paraphrasing itself is subcategory from support strategy.

Next, the article investigated reading strategy by Iranian male and female EFL learners [7]. The results showed that male and female are not different in overall reading strategy used. Female in this study are reported as greater strategy use than male students in problem-solving subscale of reading strategies. In this study, males are greater strategy use in sub-category of global strategy, it is reviewing the text first by noting its length and organization. Male students used to make a note of the overall text and organized it become a better summarize. Females in this study outperform in three sub-category of problem-solving reading strategies which are : when they confuse about what they read, they stop from time to time to think about it, when the text become difficult, the student used to repeat the reading to get better understanding, and they do guessing the meaning of the difficult words or phrases. Females also outperform in two sub-category of support reading strategy which are read aloud and go back and forth in reading the text to get better comprehension. The last, it found that females had a higher performance in sub-category of global reading strategy, it was guessing the content of the text.

Moreover, the study of reading strategy by male and female of high school students in Taiwan [16]. This study was resulted that the female students are different in the strategy use with male students. The results found that both male and female used problem-solving reading strategy and the females is higher frequency use than males. Next, it followed by global reading strategy and support strategy, where the females are a higher frequency use than males. So, the conclusion in this study showed that females are the greater awareness of reading strategy than males in all three sub-categories.

Finally, the last article is about reading strategy used by male and female students in Malaysia [5]. In this study they found that males and females are significantly different in the usage of reading strategy. Female students prefer to use global reading strategy the most, which are, they always visualize spelling of the new words as they make a visual picture of information they get from the text, and try to remember about what they read. They also tend to do back and forth in reading the text to find association between the ideas they get from the text. The last of the strategy that female students used are always remember about what they read. Male students in this study tend to use remember about what they read from the text to help them connecting the whole contents of the text, then they like to do back and forth to get more understanding about what they read like specific information and ideas in the text, they also like to stop from time to time when they read the text for thinking about what they already read.

\section{CONCLUSIONS}

It seems that the application of reading strategy is necessary while the learners try to comprehend the text. A different characteristic of each gender makes them differ in applying the strategy. The results showed the differences between males and females in the usage of reading strategy. There is a significant difference between males and females in the use of reading strategy. Male students reported greater strategy use than the female students on memory strategy, cognitive strategy, and compensation strategy. While fewer reported than females for socialaffective and meta-cognitive strategy use. In other words, males prefer global strategy and females tend to problemsolving strategies.

This implication can help the teachers be more understanding of how their students (male and female students) access passage of the text and use the reading strategies actually. Moreover, detailed analyses on each strategy use presented teachers and researchers with an upgraded awareness of the differences between male and female readers through the reading test or during their interaction with a text. The findings will enlarge the teacher's way of teaching reading of different genders. It also helps the learners to build the awareness of strategy use in their reading comprehension and they can enjoy reading and get more understanding if they use the appropriate strategy. The effectiveness of reading strategy can make improvements in the use of language instructors and the right implication by the learners.

\section{ACKNOWLEDGMENT}

The writers would like to thanks anybody who has helped them with the study. First, their parents and all of the family for the support mentally and physically. To the advisor who has given comments and suggestions for a better product and also all of friends and colleagues for the suggestion and prays.

\section{REFERENCES}

[1] F. Thresia, "The Correlation Among Reading Strategies, Reading Comprehension Achievement and Gender Differences of the Second Year Students of SMP Negeri 17 Palembang," vol. 1, 2012, ISSN. 2089-3345

[2] S. M. PEART, "L2 Reading: Strategies and Gender Preferences in the Foreign Language Classroom," Lenguaje y textos, 45, 17-27, 2017. http://doi.org/10.4995/lyt.2017.7437 
[3] D. U. Seyler, "The Reading Context: Developing Reading Skill," New York: Longman, 2004.

[4] C. T. Linse, Practical English Language Teaching: Yong Learners. New York: McGraw Hill Companies, Inc. 2005.

[5] E. I. Edward, C. S. J. Pudin, and W. A. Din, "The Usage of Reading Strategies between Male and Female Malaysia Undergraduate Students: A Preliminary Study," International Journal of Advanced Research in Education and Society, 4248, 2010, e-ISSN: 2682-81.

[6] N. Phan, "Effective Reading", Retrieved from http://www.asian-efl-journal.com /pta_october_06_np.php. 2006.

[7] S. K. Kamran, "Diversity in Utilization of Reading Strategies: A Cross Gender," Study in English Language Teaching Vol. 1, 172-186, 2013.

[8] E. Block, "The Comprehension Strategies of Second Language Readers," 20. TESOL Quarterly, 463-494, 1986.

[9] R. Oxford, Language learning strategies: What every teacher should know. Rowley: Mass: Newbury House, 1990.

[19] K. Mokhtari and R. Sheorey, "Measuring ESL Students' Awareness of Reading," Journal of Development Education, 25, 2-10, 2002.

[11] A. Poole, "Gender Differences in Reading Strategy Used Among ESL College Students," Journal of College Reading and learning, 7-2, 2005, DOI: 10.1080/10790195.2005.10850177.

[12] R. L. Oxford, and M. Nyikos, "Variables Affecting Choice of Language Learning Strategies by University Students," Modern Language Journal, 73, 291-300, 1989.

[13] A. Poole, "The Reading Strategies Used by Male and Female Colombian University Student," PROFILE 11., 29-40 2009, ISSN 1657-0790.

[14] M.-L. Lee, "A Study of the Selection of Reading Strategies Among Genders by College Students," Procedia - Social and Behavioral Sciences, 310319, 2012.

[15] S. Taki and G. H. Soleimani, "Online Reading Strategy Use and Gender Differences: The Case of Iranian EFL," Mediterranean Journal of Social Sciences, Vol. 3, 171-181, 2012, DOI: 10.5901/mjss.2012.v3n2.173.

[16] K.T-C. Chen and S.C-L. Chen, "The Use of EFL Reading Strategies among High School Students in Taiwan," The Reading Matrix: An International Online Journal. Volume 15, 156-165. 2015.

[17] K. Mokhtari and C. Reichard, "Assesing Students' Metagognitive Awareness of Reading Strategies," Journal of Educational Psychology, , 249-259, 2002. 